\title{
New Triterpenoid Glycosides from the Stem Bark of Samanea Saman
}

\author{
Nidhi Srivastava
}

\begin{abstract}
From the stem bark of Samanea saman two new triterpenoid glycoside have been isolated and characterized as $3 \beta$, $22 \beta$-dihydroxyolean -12-ene-24-0- $\beta$-D-xylopyranoside 1 and $1 \beta$, $2 \alpha, \quad 3 \beta$-trihydroxy-16 $\beta$-0-acetylolean-12-ene-28-oic-0 $\quad[-\beta$-Darabinopyranosyl $(1 \rightarrow 3)$ ] - $\beta$-D-arabinopyranoside 2 by spectral and chemical studies.
\end{abstract}

Keyword: Samanea saman, triterpenoid, glycoside

\section{INTRODUCTION}

Samanea saman (Mimosaecae) commonly called "Raintree" is a useful medicinal plant distributed from Yucatan Peninsula, Guatemala to Peru, Bolivia, Brazil, throughout the West Indies, in old world tropics and also in Southern Florida ${ }^{1}$. It is used as an alcoholic source ${ }^{2}$. It is used for cold, diarrhea, headache, intestine ailments, stomachach $^{3}$, stomach cancer $^{4}$, sore throat ${ }^{5}$. Earlier alkaloids, lupeol, lupeone, octaconsanolic acid, hexacosanol, flavonoids, kaempferol ${ }^{6}$ have been isolated from the different parts of Samanea saman.

'In continuation of our research on the chemical investigation of medicinal plants, we report herein isolation and structure elucidation of two new triterpenoid glycosides from Samanea saman.

The water insoluble portion of the hot ethanol extract of the air-dried crushed and defatted stem barks of S. saman on column chromatography yield compound $\mathbf{1}$ and $\mathbf{2}$.

\section{RESULT AND DISCUSSION}

Compound 1C35H58O7, a glycoside on acid hydrolysis gave $\mathrm{D}$-xylose and an aglycone1a. The aglycone gave colour reactions7-10 of unsaturated pentacyclictriterpenoid. It formed triacetate on acetylation showing the presence of three hydroxyl group. The IR spectrum of 1a showed absorption for hydroxyl (3450 cm-1), trisubstituted double bond (1630 cm-1), primary and secondary alcoholic group (1250, 1100, $1050 \mathrm{~cm}-1)$ and C-methyl (2900, 1385 and $1330 \mathrm{~cm}-1)$ groups. The 1 HNMR spectrum of 1 a showed signals for seven tertiary methyl groups at $(\delta 0.85,0.95$, 0.99, 1.03, 1.17, 1.31 and 1.35 (each $3 \mathrm{H}, \mathrm{S}$ ) and a vinyl proton at $\delta 5.25(1 \mathrm{H}, \mathrm{t}, \mathrm{J}=3.3 \mathrm{~Hz})$ all of which suggested $1 \mathrm{a}$ to be an olean-12-ene derivative.

The mass spectrum of 1 a revealed important peaks at $\mathrm{m} / \mathrm{z}$ 234, 224, 210, 216, 204, 201 and 175 typical of retroDiels-Alder fragmentation of ring-C of olean-12-ene derivative containing a hydroxyl group in ring A or B11.

Revised Manuscript Received on March 10, 2020.

* Correspondence Author

Nidhi Srivastava*, Associate professor, Dept. of Chemistry, P.P.N. College, Kanpur, India. E-mail: nidhi.srivastava2006@gmail.com

(C) The Authors. Published by Blue Eyes Intelligence Engineering and Sciences Publication (BEIESP). This is an open access article under the CC BY-NC-ND license (http://creativecommons.org/licenses/by-nc-nd/4.0/)
Compound 1a also gave positive Zimmermann test12 suggesting the C-3 position for this hydroxyl group which was also biogenetically favoured.

The aglycone showed signal at $\delta 3.83(1 \mathrm{H}, \mathrm{dd}, J=9.6 \mathrm{~Hz})$ with higher value of coupling constant confirming the $\beta$ orientation for hydroxyl group at C-3 ( $\alpha$ or axial $\mathrm{H}) 13$.

The ion peak at m/z 216[234-H2O) due to ready loss of water molecule showed the position of $-\mathrm{OH}$ group at $\mathrm{C}-22$ which was also supported by the ${ }^{13} \mathrm{C}-\mathrm{NMR}$ signal at $\delta 75.6(\mathrm{~d})$ for $\mathrm{C}-22$. The ${ }^{1} \mathrm{H}-\mathrm{NMR}$ signals at $\delta 4.35$ and 4.52 (each $1 \mathrm{H}, \mathrm{d}, J=12.1 \mathrm{~Hz}$ ) were attributed to the methylene protons of hydroxymethyl group (AB system) $)^{14}$. Signal at $\delta 64.5$ in ${ }^{13} \mathrm{C}$-NMR spectrum of 1a confirmed the presence of $\mathrm{CH}_{2} \mathrm{OH}$ group at $\mathrm{C}-24$. Thus, aglycone1a was identified as $3 \beta$, 22 $\beta$, 24-trihydroxyolean-12-ene.

The ${ }^{1} \mathrm{H}-\mathrm{NMR}$ spectrum of $\mathbf{1}$ showed a signal for an anomeric proton at $\delta 4.98(1 \mathrm{H}, \mathrm{d}, J=6.5 \mathrm{~Hz}, \mathrm{H}-1$, xylose) and sugar protons at $\delta 3.2-3.8$ (br, xylosyl protons) which was consistent with configuration of $\mathrm{D}$-xylose. The $\beta$-type of glycosidic linkage was also confirmed by hydrolysis of $\mathbf{1}$ with the enzyme emulsin. The position of attachment of Dxylose at C-24 hydroxyl group was confirmed by down field signal at $\delta 74.5(\mathrm{t})$ in the 13C-NMR of $\mathbf{1}$ for C-24. Thus the compound 1 was characterized as $3 \beta$, 22 $\beta$-dihydroxyolean -12-ene-24-O- $\beta$-D-xylopyranoside.

Compound 2, $\mathrm{C}_{42} \mathrm{H}_{68} \mathrm{O}_{16}\left(\mathrm{M}^{+}\right.$828), mp280 ${ }^{\circ} \mathrm{C}$, a nonreducing glycoside gave aglycone2aon acid hydrolysis with $7 \%$ $\mathrm{H}_{2} \mathrm{SO}_{4}$ anda sugar arabinose (Co-chromatographed with an authentic sample). Compound $2 \mathbf{a}, \mathrm{C}_{32} \mathrm{H}_{50} \mathrm{O}_{7}\left(\mathrm{M}^{+}\right.$546), gave colour reactions characteristic of unsaturated pentacyclic triterpenoid. Its IR spectrum showed absorption peaks for hydroxyl groups (3300 $\mathrm{cm}^{-1}$ ), trisubstituted double bond (1640 $\mathrm{cm}^{-1}$ ) and carboxylic group (3200 \& $1700 \mathrm{~cm}^{-1}$ ) and peak for $\mathrm{OCOCH}_{3}$ group $\left(1690 \& 1100 \mathrm{~cm}^{-1}\right)$. The ${ }^{1} \mathrm{HNMR}$ spectrum of 2a sowed signals for seven tertiary methyl groups between $\delta 0.85-1.31$ (each $3 \mathrm{H}, \mathrm{S}$ ), a vinylic proton at $\delta 5.34(1 \mathrm{H}, \mathrm{t}, J=$ $3.4 \mathrm{H}_{2}$ ) all of which suggested $2 \mathbf{a}$ to be an olean-12-ene derivative.

In ${ }^{1} \mathrm{HNMR}$ singlet at $\delta 2.03(3 \mathrm{H}, \mathrm{S})$ shows the presence of $-\mathrm{OCOCH}_{3}$ group. Which was also confirmed by singlet at $\delta 169.4$ and quartet at $\delta 20.4$ in ${ }^{13} \mathrm{C}$-NMR. On acetylation aglycone furnished tetraacetylated product and further methylation with diazomethane provided its monomethyl ester. These results clearly suggested the presence of three hydroxyl, one $-\mathrm{OCOCH}_{3}$ and one acidic group in the aglycone $\mathbf{2 a}$.

Acetylated product of 2a showed signals for three hydroxymethine protons signals in its ${ }^{1} \mathrm{HNMR}$ spectrum at $\delta 3.22$ $(1 \mathrm{H}, \mathrm{d}, J=10.7 \mathrm{~Hz}), 3.41(1 \mathrm{H}, \mathrm{d}, J=9.5 \mathrm{~Hz})$ for $\mathrm{H}-1$ and $\mathrm{H}-3$, and at 4.03 (dd, $1 \mathrm{H}, J_{1}=9.5 \mathrm{~Hz}$ and $J_{2}=10.7 \mathrm{~Hz}$ ) for $\mathrm{H}-2$ and for three acetoxymethine protons at $\delta 4.80\left(1 \mathrm{H}, \mathrm{d}, J_{1}=10.5 \mathrm{~Hz}\right.$ and $J_{2}=9.3$ $\mathrm{Hz}$ ) which were assigned as C-1 (or C-3), C-3 (or C-1) and C-2.

Published By:

Blue Eyes Intelligence Engineering 
The $J$ values of these signals indicated its trans-diaxial correlated protons of these three hydroxyl groups must be equatorial ${ }^{15}$.

The mass spectrum of aglycone showed the presence of both the groups $\left(-\mathrm{COOH}\right.$ and $\left.-\mathrm{OCOCH}_{3}\right)$ in ring $\mathrm{D} / \mathrm{E}$, peaks at $\mathrm{m} / \mathrm{z}$ 306, 240 obtained due to retro Diels Alder fragmentation and subsequent fragments 261 (306-COOH), $247\left(306-\mathrm{OCOCH}_{3}\right), 202\left(-\mathrm{COOH}-\mathrm{OCOCH}_{3}\right)$ and $-\mathrm{COOH}$ group must be present at $\mathrm{C}-16$ and $\mathrm{C}-17$, respectively. On compairing the ${ }^{13} \mathrm{C}-\mathrm{NMR}$ values of aglycone with $16 \beta$-Oacetyl-28 oicacid ${ }^{16}$ confirmed the above result. The larger $J$ value $(\delta 3.32, \mathrm{t}, J=17.0 \mathrm{~Hz}$ ) showed equatorial orientation of $-\mathrm{OCOCH}_{3}$ group at $\mathrm{C}-16$. On the basis of above facts 2a was identified as $1 \beta, 2 \alpha, 3 \beta$ - trihydroxy- $16 \beta$-O-acetylolean12-ene-28-oic acid.

Easy hydrolysis of glycoside with acid as well as base ${ }^{17}$ $\left[5 \mathrm{~N}-\mathrm{NH}_{4} \mathrm{OH}\right]$ confirmed that sugar was attached by ester linkage. Quantitative estimation and molecular weight difference suggested the presence of two moles of sugar per mole of aglycone. ${ }^{1} \mathrm{H}-\mathrm{NMR}$ spectrum of compound showed signals of two anomeric protons compound showed signals of two anomeric protons at $\delta 4.90(1 \mathrm{H}, \mathrm{d}, J=5.2 \mathrm{~Hz})$ and 5.76 $(1 \mathrm{H}, \mathrm{d}, J=7.5 \mathrm{~Hz})$. This confirmed that glycoside was dissacharide. On permethylation followed by acid hydrolysis permethylated derivative gave 2,4 di-O-methyl-D-arabinose and 2,3,4-trimethyl-O-D-arabinose. This confirmed that interglycosidic linkage was $(1 \rightarrow 3)$. comparing the 13C-NMR spectral data with $\mathbf{2}$ and $\mathbf{2 a}$ which showed the attachment of sugar to C-28 by higher $\delta$ value at C-28 for 2 and lower $\delta$ value of 2a. Hydrolysis of $\mathbf{2}$ with emulsion gave $\mathrm{D}$-arabinose confirming the $\beta$-nature of glycosidic linkage.

From the above evidences the structure of compound 2 was determined as $1 \beta, 2 \alpha, 3 \beta$-trihydroxy- $16 \beta$-0-acetylolean12-ene-28-oic-0 [- $\beta$-D-arabinopyranosyl $(1 \rightarrow 3)] \quad-\beta$-Darabinopyranoside.

\section{EXPERIMENTAL SECTION :}

The stem bark of Samanea saman was collected in April, 1999 from the Botany Department, University of Allahabad, Allahabad, U.P., India. M.ps measured in open capillary tube and are corrected. ${ }^{1} \mathrm{HNMR}$ and ${ }^{13} \mathrm{CNMR}$ spectra were recorded on a JEOLUNK-A 500 spectrometer in $\mathrm{CDCl}_{3}$ using TMS as an internal standard at $300 \mathrm{MHz}$ and $100 \mathrm{MHz}$, respectively. IR spectra were run in $\mathrm{KBr}$ pellets. Mass spectra were recorded on JEOLSX 102/DA-6000 mass spectrophotometer.

The air-dried and finely crushed stem bark $(5 \mathrm{~kg})$ of Samanea saman was repeatedly extracted with boiling EtOH (4x10l), concentrated under reduce pressure in a rotatory evaporator and poured into an excess of ice-cold distilled water with constant stirring to give reddish brown aqueous solution (fraction-I) and light brown residue (fraction-II) were obtained. The water insoluble portion was extracted successively with different solvents of increasing polarity over a sintered Column. Elution with solvent system $\mathrm{C}_{6} \mathrm{H}_{6}$ : EA $(9: 1, v / v)$ followed by runing in preparative TLC using benzene:chloroform $(9: 1, \mathrm{v} / \mathrm{v})$ marked with the help of UV lamp gave compounds $\mathbf{1}(0.69 \mathrm{~g})$, and from pure ethyl acetate followed by runing in preparative TLC using ethylacetate : methanol(9:1, v/v), compond 2 (0.35g) were obtained.
The attachment of two sugar moieties were confirmed by

Compound 1, mp. $136^{\circ} \mathrm{C}$, yield $690 \mathrm{mg}$, homogenous on TLC, $\mathrm{R}_{\mathrm{f}} 0.46$ solvent $\mathrm{C}_{6} \mathrm{H}_{6}: \mathrm{CHCl}_{3}(9: 1, \mathrm{v} / \mathrm{v})$; Anal. Found: C, 71.10; H, 9.82; Calcd. for $\mathrm{C}_{35} \mathrm{H}_{58} \mathrm{O}_{7}$ : C, 71.15; $\mathrm{H}, 9.89 \%$ . IR (KBr) 3450, 2923, 1630, 1100, 1050. ${ }^{1} \mathrm{HNMR}\left(\mathrm{CDCl}_{3}\right.$, $300 \mathrm{MHz}$ ) : $\delta 0.85$ (s, 3H, H-25), 0.95 (s,3H, H-26), 0.99 (s,3H, H-29), 1.03 (s,3H, H-30), 1.17 (s,3H, H-27), 1.31 (s,3H, H-28), 1.35 (s,3H, H-23), 2.59 (brs,1H, J=13Hz), 3.83 (dd, $1 \mathrm{H}, J=9.6 \mathrm{~Hz}, \beta-\mathrm{OH}$ at C-3), 5.25 (t, $1 \mathrm{H}, J=3.3$ $\mathrm{Hz}$ ), 4.35 and 4.52 (d, $1 \mathrm{H}, J=12.1 \mathrm{~Hz}$ for $-\mathrm{CH}_{2} \mathrm{OH}$ group proton), 4.98 (d, $1 \mathrm{H}, J=7 \mathrm{~Hz}$ for $\beta$ linkage) and 3.2-3.8 (m,

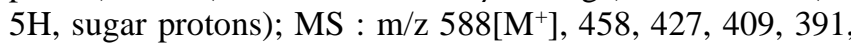
234, 224, 219, 216, 204, 201, 175, 119; ${ }^{13} \mathrm{C}-\mathrm{NMR}$ data are given in Table-I.

Compound 2, mp. $280^{\circ} \mathrm{C}$, yield 350mg, homogenous on TLC, Rf 0.64 solvent $\mathrm{CHCl}_{3}: \mathrm{MeOH}(8: 2, \mathrm{v} / \mathrm{v})$; Anal. found : C, 59.99; 8.23; Calcd for $\mathrm{C}_{42} \mathrm{H}_{68} \mathrm{O}_{16}$ : C, 60.85; $\mathrm{H}$, $8.24 \%$; IR (KBr) 3300, 3200, 1700, 1690, 1640, 2933, 1381, 1362, 1100, 970; ${ }^{1} \mathrm{HNMR}\left(\mathrm{CDCl}_{3}, 300 \mathrm{MHz}\right): \delta 0.85$ (s, 3H, H-25), 0.93 (s, 3H, H-26), 0.95 (s, 3H, H-29), 1.04 (s, 3H, $\mathrm{H}-30$ ), 1.17 (s, 3H, H-27), 1.24 (s, 3H, H-28), 1.31 (s, 3H, $\mathrm{H}-23$ ), 2.03 (s, 3H, $-\mathrm{OCOCH}_{3}$ ), 5.34 (t, 1H, J=3.4 Hz), 4.80 (d, $1 \mathrm{H}, J=10.5 \mathrm{~Hz}$ ), 4.88 (d, 1H, J=9.3Hz), 520 (dd, $1 \mathrm{H}$, $J=10.5$ and $9.3 \mathrm{~Hz}$ ), 3.22 (d, $1 \mathrm{H}, J=10.7 \mathrm{~Hz}, \mathrm{H}-1$ ), 3.41 (d, $1 \mathrm{H}, J=9.5 \mathrm{~Hz}, \mathrm{H}-3$ ), 4.03 (dd, $1 \mathrm{H}, J=10.7$ and $9.5 \mathrm{~Hz}, \mathrm{H}-2$ ), 4.90 (d, $1 \mathrm{H}, J=5.2 \mathrm{~Hz}$ ), 5.76 (d, $1 \mathrm{H}, J=7.5 \mathrm{~Hz}), 3.25-3.85$ (m, $10 \mathrm{H}$, sugar protons); MS : m/z $828\left[\mathrm{M}^{+}\right], 546,306,261$, 247, 240, 202; ${ }^{13}$ CNMR data are given in Table-II.

\section{CONCLUSION:}

In conclusion Samanea saman is a rich source of trirepenoid. Trirepenoid are of great interest due to many biological activity and several parts of the plants have a particular pleasant smell. This smell is due to the presence of certain volatile oil known as essential oil. Among the chief constituent of essential oil are triterpenoid upto $C_{15}$ Due to their biological activity and characteristic smell, plants are used in pharmacy and perfumery industry respectivety.

\section{REFERENCES}

1. James Duke, A, Handbook of Energy Crop,1983.

2. CSIR (Council of Scientific and Industrial Research) The Wealth of India, New Delhi, 11, 1948-1976.

3. Duke, J.A. \&Wain KK, Medicinal Plants of the World, 3, 1981.

4. Hartwell JL, Plants used against Cancer, A survey Lloydia, 30-34, 1967-1971.

5. Ayensu, ES, Medicinal Plants of the West Indies, Reference Publications, Inc., Algonac, MI, 1981, 282.

6. List PH and Horhamner L, Hager's handbuchderpharmazeutischen praxis, Springer, Verlag, Berlin, 2-6, 1969-1979.

7. Liebermann C, Ber Deutsch Chem. Ges., 1885, 1804.

8. Takahashi K, Kawashi S, NishmuraKT, Kutota K, Tanabe Y and Takani M, Chem Pharm Bull, 22, 1974. 650.

9. Brieskorne $\mathrm{CH}$ and Briner B, Pharm ActaHelv, 28, 1953, 139

10. Ruzicka L and Leibigs, Ann Chem, 25, 1929, 471.

11. Takahashi K, Tanka O and Shibata S, Phytochemistry, 8, 1969, 2345.

12. Barton DHR and De Mayo P, J ChemSoc.,1954, 887.

13. Rogers OB and Subramony G, Phytochemistry, 27, 1988, 531.

14. Sanghi R, Tripathi K and Sharma JP, Indian J Chem.39B, 2000, 477.

15. Srivastava M and Singh J, Int. J. Pharmacoy, 32, 1994, 197.

16. Rai R, Gupta A, Chauhan D, Purwar C and Singh J, Pharmaceutical Biology, 39, 2001, 413.

17. Hariharam V and Rangaswami S, Phytochemistry, 9, 1970, 409. 


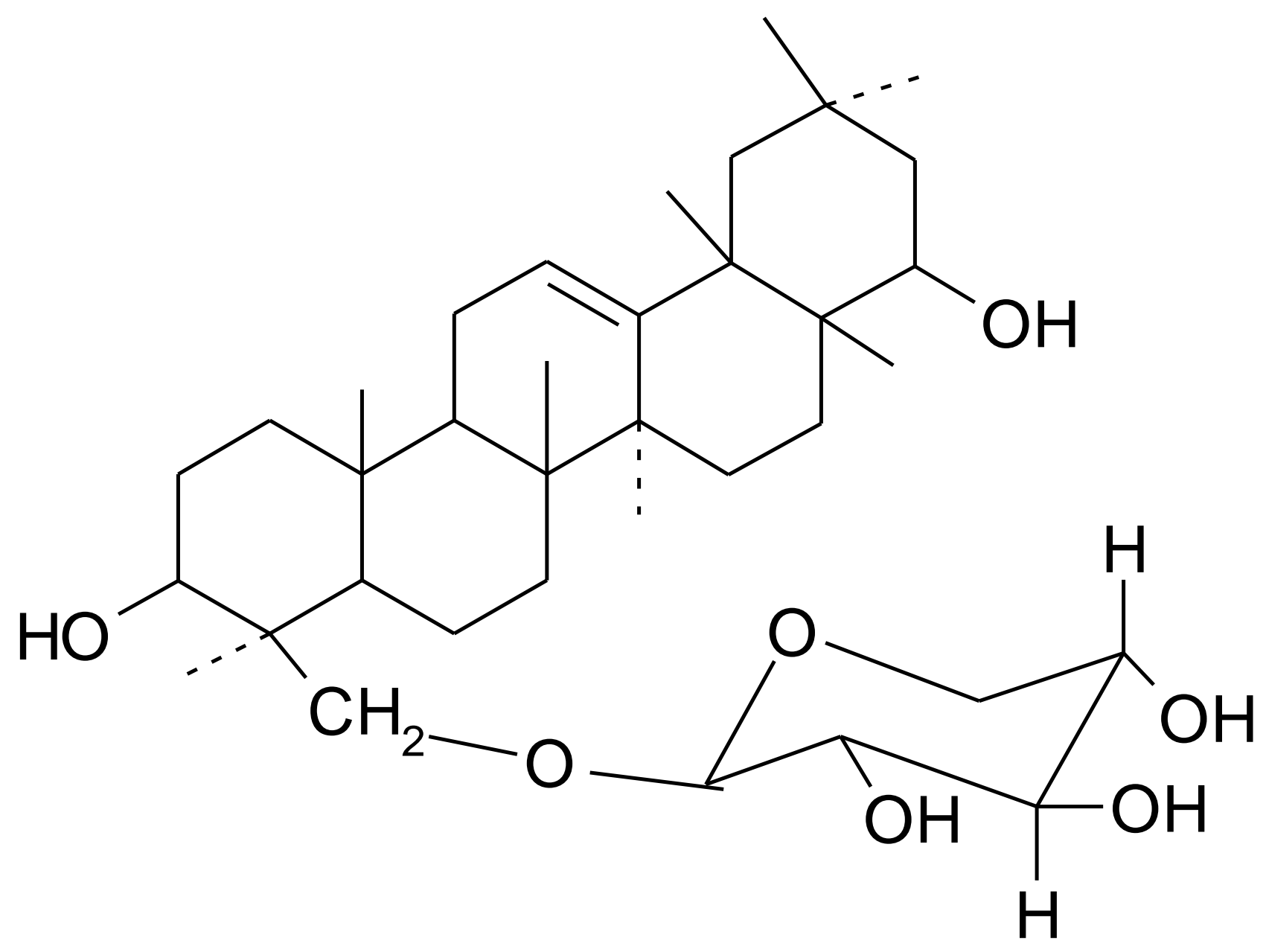

$3 \beta, 22 \beta$ - dihydroxyolean -12-ene-24-O- $\beta$-D-xylopyranoside1

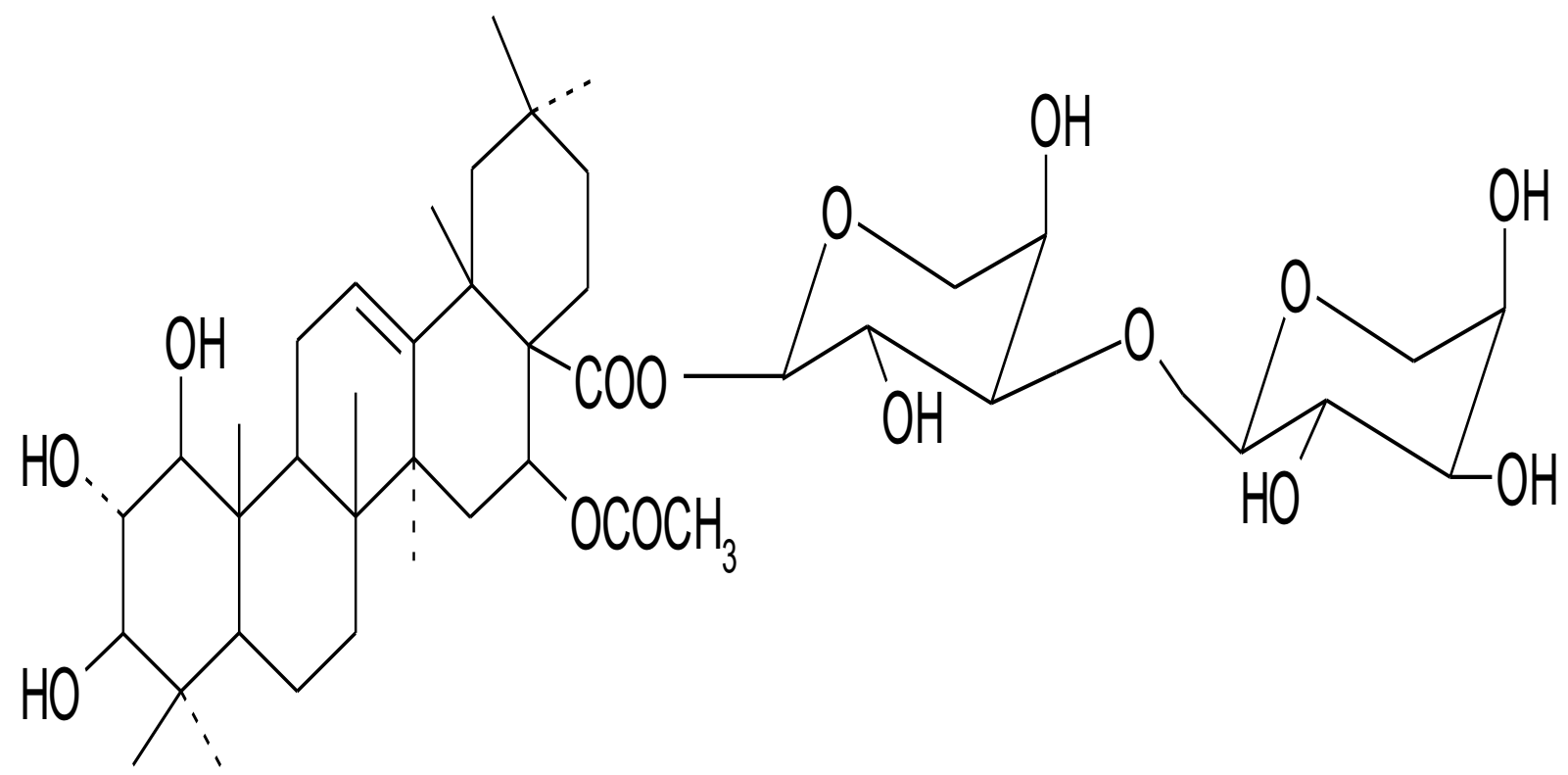

$1 \beta, 2 \alpha, 3 \beta$-trihydroxy-16 $\beta$-O-acetylolean-12-ene-28 oic acid-28-O-

[- $\beta$-D-arabinopyranosyl $(1 \rightarrow 3)]-\beta$-D-arabinopyranoside2

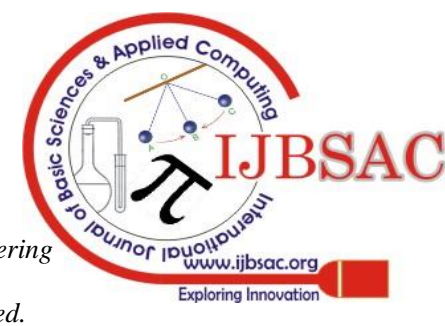


New Triterpenoid Glycosides from the Stem Bark of Samanea Saman

Table $-\mathrm{I} .{ }^{13} \mathrm{C}-\mathrm{NMR}(\boldsymbol{\delta})$ values of glycoside SS-1 and its aglycone

\begin{tabular}{|c|c|c|}
\hline Chemical Assigned & $\begin{array}{l}\text { Glycoside Chemical } \\
\text { Shift (ppm) }\end{array}$ & $\begin{array}{l}\text { Aglycone Chemical } \\
\text { shift (ppm) }\end{array}$ \\
\hline $\mathrm{C}-1$ & $38.6(\mathrm{t})$ & $39.0(\mathrm{t})$ \\
\hline $\mathrm{C}-2$ & $27.5(\mathrm{t})$ & $28.4(\mathrm{t})$ \\
\hline $\mathrm{C}-3$ & $80.0(\mathrm{~d})$ & 79.8(d) \\
\hline C-4 & $43.0(\mathrm{~s})$ & $43.0(\mathrm{~s})$ \\
\hline $\mathrm{C}-5$ & $57.0(\mathrm{~d})$ & 56.3(d) \\
\hline $\mathrm{C}-6$ & $19.2(\mathrm{t})$ & $19.4(\mathrm{t})$ \\
\hline $\mathrm{C}-7$ & $33.7(\mathrm{t})$ & $33.5(t)$ \\
\hline $\mathrm{C}-8$ & $40.1(\mathrm{~s})$ & $39.9(\mathrm{~s})$ \\
\hline C-9 & 48.6(d) & 48.1(d) \\
\hline $\mathrm{C}-10$ & $36.8(\mathrm{~s})$ & $37.0(\mathrm{~s})$ \\
\hline C-11 & $24.6(\mathrm{t})$ & $24.0(\mathrm{t})$ \\
\hline $\mathrm{C}-12$ & $123.0(\mathrm{~d})$ & 122.4(d) \\
\hline $\mathrm{C}-13$ & $145.0(\mathrm{~s})$ & $144.9(\mathrm{~s})$ \\
\hline C-14 & $42.0(\mathrm{~s})$ & $42.3(\mathrm{~s})$ \\
\hline C-15 & $26.0(\mathrm{t})$ & $26.4(\mathrm{t})$ \\
\hline C-16 & $29.4(\mathrm{t})$ & $29.0(\mathrm{t})$ \\
\hline $\mathrm{C}-17$ & $37.5(\mathrm{~s})$ & $38.4(\mathrm{~s})$ \\
\hline C-18 & 44.5(d) & 44.8(d) \\
\hline C-19 & $41.9(\mathrm{t})$ & $41.5(\mathrm{t})$ \\
\hline $\mathrm{C}-20$ & $30.5(\mathrm{~s})$ & $30.0(\mathrm{~s})$ \\
\hline $\mathrm{C}-21$ & $37.0(\mathrm{t})$ & $37.3(\mathrm{t})$ \\
\hline $\mathrm{C}-22$ & 75.6(d) & 75.6(d) \\
\hline C-23 & 23.1(q) & $23.5(q)$ \\
\hline $\mathrm{C}-24$ & $74.5(\mathrm{t})$ & $64.5(\mathrm{t})$ \\
\hline $\mathrm{C}-25$ & 16.2(q) & $16.3(\mathrm{q})$ \\
\hline $\mathrm{C}-26$ & $17.5(\mathrm{q})$ & 17.1(q) \\
\hline $\mathrm{C}-27$ & $26.8(q)$ & $25.5(\mathrm{q})$ \\
\hline $\mathrm{C}-28$ & 21.1(q) & 21.1(q) \\
\hline C-29 & $32.5(\mathrm{q})$ & $32.0(q)$ \\
\hline C-30 & $24.6(q)$ & $24.4(q)$ \\
\hline $\mathrm{C}-1^{\prime}$ & $103.6(q)$ & \\
\hline $\mathrm{C}-2^{\prime}$ & $71.5(\mathrm{q})$ & \\
\hline C-3' & 75.2 (d) & \\
\hline C-4' & $70.1(d)$ & \\
\hline C-5' & $67.6(\mathrm{t})$ & \\
\hline
\end{tabular}

\begin{tabular}{|c|c|l|}
\hline C-1 $^{\prime}$ & $105.6(\mathrm{~d})$ & \\
\hline C-2 $^{\prime}$ & $73.8(\mathrm{~d})$ & \\
\hline C-3 $^{\prime}$ & $74.6(\mathrm{~d})$ & \\
\hline C-4' $^{\prime}$ & $70.2(\mathrm{~d})$ & \\
\hline C-5 $^{\prime}$ & $67.0(\mathrm{t})$ & \\
\hline C-1 $^{\prime}$ & $104.5(\mathrm{~d})$ & \\
\hline C-2 $^{\prime}$ & $73.0(\mathrm{~d})$ & \\
\hline C-3' $^{\prime}$ & $72.1(\mathrm{~d})$ & \\
\hline C-4 $^{\prime}$ & $70.0(\mathrm{~d})$ & \\
\hline C-5 & $67.5(\mathrm{t})$ & \\
\hline
\end{tabular}

\section{AUTHORS PROFILE}

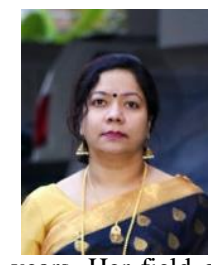

Dr. Nidhi Srivastava is Associate Professor \& Head of the Department of Chemistry in P.P.N college Kanpur, affiliated to CSJM University, Kanpur. She obtained his graduation, post-graduation and D.Phil degree from University of Allahabad, Allahabad. She qualified JRF (NET)-2001 and MP (SLET)-2000. And also work as SRF(CSIR) for two years. She has a long teaching experience of UG and PG classes from last 20 years. Her field of research mainly includes isolation of natural products their identification characterization and screening effect. Dr. Nidhi Srivastava has participated and delivered lectures at various seminars, conferences. She is also a member of several professional societies.

Table -II. 13C-NMR ( $\delta$ ) values of glycoside SS-2 and its aglycone

\begin{tabular}{|c|c|c|}
\hline Chemical Assigned & $\begin{array}{l}\text { Glycoside Chemical } \\
\text { Shift (ppm) }\end{array}$ & $\begin{array}{l}\text { Aglycone Chemical } \\
\text { shift (ppm) }\end{array}$ \\
\hline $\mathrm{C}-1$ & $74.6(\mathrm{~d})$ & $74.4(\mathrm{~d})$ \\
\hline $\mathrm{C}-2$ & $74.8(\mathrm{~d})$ & $74.8(\mathrm{~d})$ \\
\hline $\mathrm{C}-3$ & $76.5(\mathrm{~d})$ & 76.3(d) \\
\hline $\mathrm{C}-4$ & $43.2(\mathrm{~s})$ & $43.2(\mathrm{~s})$ \\
\hline C-5 & $57.2(d)$ & 57.3(d) \\
\hline C-6 & $19.2(\mathrm{t})$ & $19.2(\mathrm{t})$ \\
\hline $\mathrm{C}-7$ & $33.6(\mathrm{t})$ & $33.6(\mathrm{t})$ \\
\hline $\mathrm{C}-8$ & $40.2(\mathrm{~s})$ & $40.1(\mathrm{~s})$ \\
\hline C-9 & 48.4(d) & 48.4(d) \\
\hline $\mathrm{C}-10$ & $36.8(\mathrm{~s})$ & $36.8(\mathrm{~s})$ \\
\hline $\mathrm{C}-11$ & $24.6(\mathrm{t})$ & $24.6(\mathrm{t})$ \\
\hline C-12 & 124.2(d) & 124.2(d) \\
\hline $\mathrm{C}-13$ & 146.1(s) & 146.1(s) \\
\hline $\mathrm{C}-14$ & $42.0(\mathrm{~s})$ & $42.0(\mathrm{~s})$ \\
\hline $\mathrm{C}-15$ & $26.3(\mathrm{t})$ & $26.3(\mathrm{t})$ \\
\hline C-16 & 81.4(d) & 81.4(d) \\
\hline $\mathrm{C}-17$ & $48.5(\mathrm{~s})$ & $48.5(\mathrm{~s})$ \\
\hline C-18 & $42.6(\mathrm{~d})$ & $42.6(d)$ \\
\hline C-19 & $39.6(\mathrm{t})$ & $39.5(\mathrm{t})$ \\
\hline $\mathrm{C}-20$ & $36.8(\mathrm{~s})$ & $36.6(\mathrm{~s})$ \\
\hline $\mathrm{C}-21$ & $37.3(\mathrm{t})$ & $37.4(\mathrm{t})$ \\
\hline $\mathrm{C}-22$ & $38.2(\mathrm{t})$ & $38.2(\mathrm{t})$ \\
\hline $\mathrm{C}-23$ & $23.2(q)$ & $23.2(q)$ \\
\hline $\mathrm{C}-24$ & $17.6(\mathrm{q})$ & $17.6(\mathrm{q})$ \\
\hline $\mathrm{C}-25$ & 16.1(q) & 16.1(q) \\
\hline $\mathrm{C}-26$ & $17.5(\mathrm{q})$ & $17.5(\mathrm{q})$ \\
\hline $\mathrm{C}-27$ & 26.8(q) & $26.8(q)$ \\
\hline $\mathrm{C}-28$ & $181.9(\mathrm{~s})$ & 179.2(s) \\
\hline C-29 & $27.4(\mathrm{q})$ & $27.3(\mathrm{q})$ \\
\hline C-30 & 17.9(q) & \\
\hline $\mathrm{OCOCH}_{3}$ & $20.5(q)$ & \\
\hline $\mathrm{OCOCH}_{3}$ & $168.7(\mathrm{~s})$ & \\
\hline
\end{tabular}

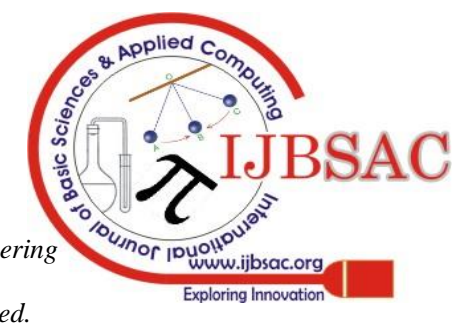

